\title{
AMMONIA VOLATILIZATION IN RESPONSE TO COATED AND CONVENTIONAL UREA IN MAIZE CROP FIELD
}

\author{
VOLATILIZAÇÃO DE AMÔNIA UTILIZANDO UREIA CONVENCIONAL E \\ REVESTIDA NA CULTURA DO MILHO
}

\begin{abstract}
Flávio Hiroshi KANEKOㅜㅜ ;oão Paulo FERREIRA² ${ }^{2}$ Aguinaldo José Freitas LEAL ${ }^{3}$; Salatiér BUZETTI ${ }^{4}$; André Rodrigues dos REIS ${ }^{5}$; Orivaldo ARF $^{6}$

1. Professor, Doutor, curso de agronomia, UFTM, Iturama MG, Brasil. flavio.kaneko@uftm.edu.br; 2. Professor Doutor, curso de agronomia; Centro Universitário Padre Albino, Catanduva SP, Brasil; 3. Professor, Doutor, curso de agronomia, UFTM, Iturama MG

Brasil; 4. Professor Titular, Departamento de fitossanidade, engenharia rural e solos, UNESP, Ilha Solteira SP, Brasil; 5. Professor Doutor, UNESP, Tupã SP, Brasil; 6. Professor titular, Departamento de fitotecnia, sócio economia e tecnologia de alimentos, UNESP, Ilha Solteira SP, Brasil.
\end{abstract}

\begin{abstract}
The properly measurement of gas emissions and nutrient availability to crops using technologies such as polymer-coated urea are required to monitored the possible nitrogen $(\mathrm{N})$ fertilizer pollution in the environment. This study aimed to evaluate $\mathrm{N}$ loss through ammonia volatilization from polymer-coated and conventional urea in maize field trials under two different environments. The study was carried out in Chapadão do Sul and Selvíria State of Mato Grosso do Sul evaluating the first and second harvest of maize plants. Nitrogen fertilizers were applied as polymer-coated, conventional urea and control plots were used as reference to evaluate $\mathrm{N}$ loss through volatilization $(3,6,9,12$, and 15 days after fertilizer application). The peak of ammonia volatilization was observed during the first three days after fertilizer application corresponding up to $44 \%$ of total $\mathrm{N}$ supplied. Polymer-coated urea had promising results showing less ammonia volatilization during the first crop. However, the same result was not observed for second crop.
\end{abstract}

KEYWORDS: Loss of N. Efficient fertilizer usage. Cerrado. Polymer. No-till planting system.

\section{INTRODUCTION}

Brazil stands out in maize production being the third largest producer worldwide. In 2016, 33\% of the total area cultivated with maize was observed during first season (spring - summer), widely known as summer maize. Despite the tropical climate conditions, soybean is early cultivated using no tillage system with harvest season between January and May (summer season). In order to harvest a second crop, farmers in South America cultivate maize after soybean cultivation. This crop rotation is called second crop system (KANEKO et al., 2016). Currently, second crop system corresponds up to $67 \%$ of cultivated area of maize in Brazil. Second crop system has been adopted in several tropical regions worldwide especially in Asia and Africa providing high quality food to alleviate human malnourishment.

Nitrogen $(\mathrm{N})$ is a key factor driving the crop yield in second crop system. Agriculture practice regarding $\mathrm{N}$ application needs improvements to avoid excess of $\mathrm{N}$ loss through leaching and volatilization (SHI et al., 2010; SUN et al., 2015; $\mathrm{KE}$ et al., 2017). These processes has been involved in global warming, and excessive delivery of nitrous oxide and ammonia from synthetic $\mathrm{N}$ fertilizer to the environment (RAVINSHANKARA et al., 2009; RAYMOND et al., 2016). Properly measurement methods to quantify the exactly amount of ammonia have been released from synthetic $\mathrm{N}$ sources are need (ADEWOPO et al., 2014).

Urea is the main $\mathrm{N}$ fertilizer used worldwide (PAN et al., 2016). Application of urea tropical soils (soil with acidic reactions) results in a massive loss of $\mathrm{N}$ through volatilization (CHIEN et al., 2009; NASH et al., 2015).

Several techniques have been development to increase the efficiency of $\mathrm{N}$ fertilizer application to crops growing in tropical environments. Coated urea with polymers is a great example to how decrease $\mathrm{N}$ loss through ammonia volatilization (SOARES et al., 2012). However, several studies show controversial results regarding the efficiency of coated urea with polymers application in crops (PEREIRA et al., 2009; NASCIMENTO et al., 2013; ZAVASCHI et al., 2014; SUN et al., 2015). Therefore, further studies are needed to quantify $\mathrm{N}$ loss through ammonia volatilization in different environments in order to recommend the optimal $\mathrm{N}$ fertilizer management. Properly management of $\mathrm{N}$ sources in agriculture can promote sustainable crop production with less environmental contamination. 
This study aimed to evaluate the ammonia volatilization to estimate the $\mathrm{N}$ loss from polymercoated and conventional urea in maize crop field under no-till system in tropical soils and environments.

\section{MATERIAL AND METHODS}

\section{Location and characterization of the study areas}

The experiments were conducted in Chapadão do Sul and Selvíria, State of Mato Grosso do Sul, Brazil. In Chapadão do Sul, the experiment was carried out at $18^{\circ} 41^{\prime} 33^{\prime}$ " latitude south and $52^{\circ} 40^{\prime} 45^{\prime \prime}$ longitude west at $810 \mathrm{~m}$ of elevation altitude (a high elevation mountain range). In Selvíria, the experiment was located at $20^{\circ} 22^{\prime}$ latitude south and $51^{\circ} 22^{\prime}$ longitude west at 335 meters of elevation (a low-elevation mountain range). The soil of both experiment sites is classified as Oxissol (SANTOS et al., 2013). The chemical properties of both soil environments are summarized in Table 1.

Table 1. Soil chemical properties from experiment sites $(0-0.20 \mathrm{~m})$.

\begin{tabular}{|c|c|c|c|c|c|c|c|c|c|}
\hline Area & O.M & $\begin{array}{l}\text { Total } \\
\mathrm{N}\end{array}$ & $\begin{array}{l}\mathrm{pH} \\
\left(\mathrm{CaCl}_{2}\right)\end{array}$ & $\begin{array}{l}\mathrm{P} \\
(\operatorname{Resin})\end{array}$ & $\mathrm{S}$ & $\mathrm{K}$ & $\mathrm{Ca}$ & $\mathrm{Mg}$ & $\mathrm{H}+\mathrm{Al}$ \\
\hline & \multicolumn{3}{|c|}{----g dm${ }^{-3}---$} & \multicolumn{2}{|c|}{------mg dm $\mathrm{mm}^{-3}------$} & \multicolumn{4}{|c|}{--------mmol $\mathrm{dm}_{\mathrm{c}}^{-3}$} \\
\hline 1 & 28 & 2.03 & 5.2 & 33 & 6 & 1.7 & 38 & 9 & 23 \\
\hline 2 & 18 & 1.04 & 5.1 & 10 & 8 & 2.8 & 25 & 13 & 21 \\
\hline 3 & 31 & 1.96 & 4.7 & 39 & 23 & 2.3 & 34 & 11 & 48 \\
\hline 4 & 28 & 1.65 & 4.9 & 58 & 14 & 7.0 & 31 & 21 & 50 \\
\hline
\end{tabular}

Selvíria shows an annual average precipitation around $1.300 \mathrm{~mm}$, average annual temperature is $23.5^{\circ} \mathrm{C}$, and relative air humidity is between 70 and $80 \%$. In Chapadão do Sul, annual average precipitation is $1.500 \mathrm{~mm}$, average annual temperature is $21{ }^{\circ} \mathrm{C}$, and relative air humidity is between 50 and $70 \%$. Maximum and minimum temperature for Chapadão do Sul and Selvíria are compiled in Figure 1 and precipitation during the monitoring period for $\mathrm{N}$ loss through volatilization are summarized in Table 2. For both environment sites, the experiments were installed in two different time periods: first and second crop maize. In Selvíria, the experiments were carried out with "central pivot" sprinkler irrigation, while in Chapadão do Sul, there was no irrigation.

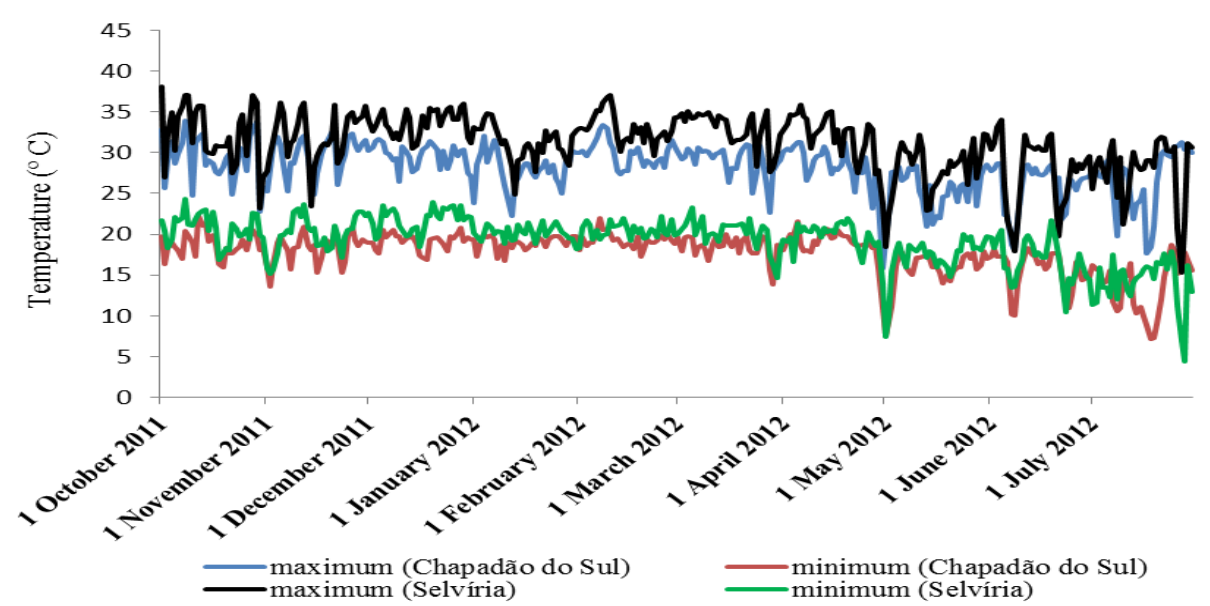

Figure 1. Maximum and minimum temperature for Chapadão do Sul and Selvíria (the state of Mato Grosso do Sul - Brazil), 2011/12 harvest. 
Maize was sown using a no-till system after soybean (Glycine $\max$ L.) and maize rotation in the spring - summer and maize and millet in autumn winter. Millet (Pennisetum glaucum (L.) R. Br.) is the antecedent crop for the first crop maize experiments. Soybean was the antecedent crop for the second crop maize experiment. Sowing date for Chapadão do Sul and Selvíria took place in
10/28/2011 and 11/11/2011 for "first harvest" maize, while the "second harvest" maize crop in Chapadão do Sul and Selvíria, the sowing took place on 02/21/2012 and 04/05/2012, respectively. For all experiments the maize were sowed with 0.45 $\mathrm{m}$ row spacing and $\mathrm{N}$ fertilizer topdressing between the crop rows.

Table 2. Last precipitation before nitrogen fertilizer application and precipitation during the monitoring period for $\mathrm{N}$ loss through volatilization, Chapadão do Sul and Selvíria (state of Mato Grosso do Sul Brazil), 2011/12 harvest.

\begin{tabular}{|c|c|c|c|c|}
\hline \multirow[b]{2}{*}{ Location } & & Last precipitation & Nitrogen fertilizer & Precipitation \\
\hline & & $\begin{array}{l}\text { Pre-fertilizer } \\
\text { period }\end{array}$ & Data & Monitoring period \\
\hline \multirow{2}{*}{$\begin{array}{l}\text { Chapadão } \\
\text { do Sul }\end{array}$} & first maize crop & $\begin{array}{l}14 \text { Nov } 2011 \\
(25 \mathrm{~mm})\end{array}$ & 21 Nov 2011 & $\begin{array}{l}21 \text { Nov } 2011(21 \mathrm{~mm}) \\
27 \text { Nov } 2011(02 \mathrm{~mm}) \\
\text { 06 Dec } 2011(03 \mathrm{~mm})\end{array}$ \\
\hline & $\begin{array}{l}\text { second } \\
\text { crop }\end{array}$ & $\begin{array}{l}18 \mathrm{Mar} 2012 \\
(16 \mathrm{~mm})\end{array}$ & 22 Mar 2012 & $\begin{array}{l}22 \operatorname{Mar} 2012(22 \mathrm{~mm}) \\
25 \operatorname{Mar} 2012(20 \mathrm{~mm}) \\
26 \operatorname{Mar} 2012(13 \mathrm{~mm}) \\
31 \operatorname{Mar} 2012(05 \mathrm{~mm})\end{array}$ \\
\hline \multirow{2}{*}{ Selvíria } & first maize crop & $\begin{array}{l}01 \mathrm{Dec} 2011 \\
(7 \mathrm{~mm})\end{array}$ & 05 Dec 2011 & $\begin{array}{l}06 \operatorname{Dec} 2011(23 \mathrm{~mm}) \\
07 \operatorname{Dec} 2011(17 \mathrm{~mm}) \\
14 \operatorname{Dec} 2011(21 \mathrm{~mm})\end{array}$ \\
\hline & $\begin{array}{l}\text { second } \\
\text { crop }\end{array}$ & $\begin{array}{l}22 \text { Apr } 2012 \\
(14 \mathrm{~mm})\end{array}$ & 26 Apr 2012 & $\begin{array}{l}27 \text { Apr } 2012(18 \mathrm{~mm}) \\
30 \text { Apr } 2012(11 \mathrm{~mm}) \\
01 \text { May } 2012(07 \mathrm{~mm})\end{array}$ \\
\hline
\end{tabular}

*Referring to rain and irrigation.

\section{Description of experimental conditions and experiment setup}

The treatments were consisted of two $\mathrm{N}$ sources: polymer-coated and conventional urea. An additional plot receiving no $\mathrm{N}$ fertilization was set as a control treatment (without $\mathrm{N}$ ). Nitrogen loss through volatilization was measured $3,6,9,12$ and 15 days after fertilizer was applied as well as the total accumulated loss throughout the period. The experiment used a completely randomized block design with 5 replications. A soluble ionic polymer was used to coat the urea (commercial name Policote ${ }^{\circledR}$ ). The $\mathrm{N}$ rate used was $135 \mathrm{~kg} \mathrm{ha}^{-1}$ applied to the soil surface during phonological maize stage at $V_{5}$. Nitrogen fertilizer was applied on $11 / 21 / 2011$ in Chapadão do Sul and 12/05/2011 in Selvíria for the first crop and on 03/22/2012 in Chapadão do Sul and 04/26/2012 in Selvíria for the second crop.

\section{Determination of ammonia volatilization}

Ammonia volatilization was quantified using a semi-open collector as described by NOMMIK (1973) and adapted by Lara Cabezas et al. (1999). The semi-open collector were constructed from transparent PVC; measured $35 \mathrm{~cm}$ tall and $15 \mathrm{~cm}$ in diameter, and accommodated two 3 -cm-thick disk-shaped pieces of polyurethane foam impregnated with phosphoric acid solution $(50 \mathrm{~mL}$ $\left.\mathrm{L}^{-1}\right)+$ glycerin $\left(40 \mathrm{~mL} \mathrm{~L}^{-1}\right)$. First, the ammonia collectors were installed on the soil at a depth of 20 $\mathrm{cm}$ to capture the ammonia volatilization from fertilizer. The second piece of foam was placed 15 $\mathrm{cm}$ above the first in order to prevent ammonia contamination from outside atmosphere. Experiment results from Jantalia et al. (2012) comparing the semi-open collector method with ${ }^{15} \mathrm{~N}$ equilibrium technique show that semi-open collector is appropriate method to measure ammonia volatilization from fertilizers.

Transparent PVC hat with $2 \mathrm{~cm}$ between the lowest part of the hat and the collector were placed 
to protect the collectors from rain. The collector was fixed in the soil by means of 3-mm-thick steel stakes as illustrated in Figure 2. The collectors were installed on rigid PVC bases $15 \mathrm{~cm}$ in diameter and $11 \mathrm{~cm}$ in height that were located between maize spacing rows. The positions of the collectors were periodically changed according to monitoring period as described by Cantarella et al. (2008).
The samples were collected from the semiopen collectors in different monitoring time for ammonia quantification. The foams located at the top of the collector were discarded. Foam located in the center of collectors (figure 2) collected and used for analysis. The foam disks were stored in plastic bags and refrigerated to a temperature of less than 5 ${ }^{\circ} \mathrm{C}$ for later quantification of volatized $\mathrm{N}$.

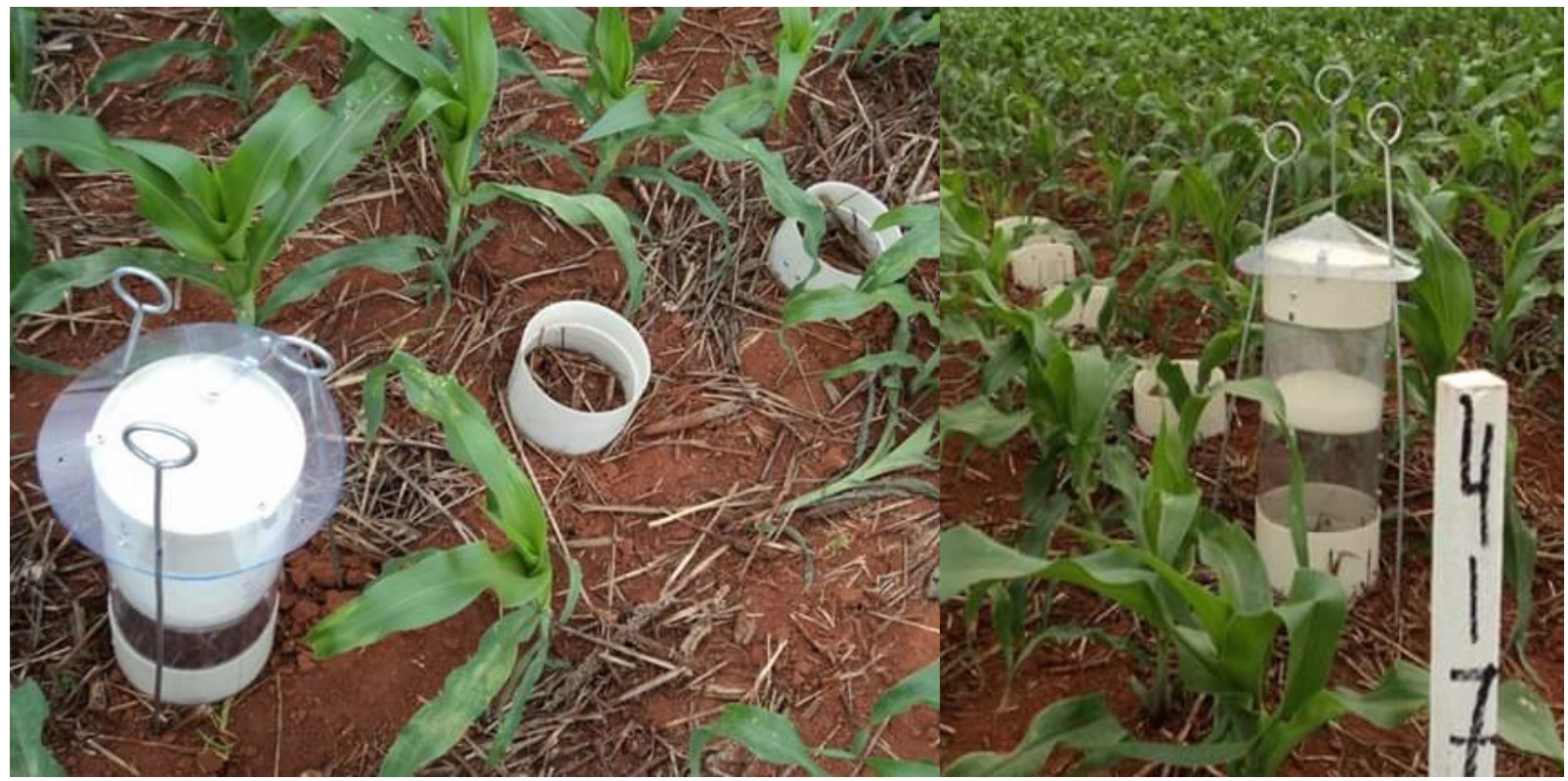

Figure 2. Semi-open static collector with absorber wrapped floam and its respective PVC bases use to quantify ammonia volatilization in maize crop field.

Ammonia extraction retained in the foam disks was carried out by saturating the disks with $400 \mathrm{~mL}$ of $1.0 \mathrm{~mol} \mathrm{~L}^{-1}$ of $\mathrm{KCl}$ solution for 24 hours in order to completely remove the ammoniacal nitrogen retained. An aliquot of the extract was distilled with $10 \mathrm{~mL}$ of $5.0 \mathrm{~mol} \mathrm{~L} \mathrm{~L}^{-1}$ of $\mathrm{NaOH}$ solution. The distillate was collected in an Erlenmeyer flask with $10 \mathrm{~mL}$ of boric acid solution containing an indicator. Afterwards, the solution was titrated with $0.05 \mathrm{~mol} \mathrm{~L}^{-1}$ hydrochloric acid (Kjedahl method). The results obtained after correcting for the background sample were expressed in $\mathrm{kg} \mathrm{ha}^{-1}$ of volatized $\mathrm{N}$.

\section{Statistical Analysis}

In all of the data sets considered, the normality of the data was analyzed using the Anderson-Darling test and verifying the homoscedasticity of the data with the variation equation test (or the Levenn test). The data underwent variation analysis with significant levels of $5 \%(\mathrm{p} \leq 0.05)$ probability by the $\mathrm{F}$ test. When they were significant, the averages underwent the Tukey test at the $5 \%$ de probability level of error using Sisvar statistical analysis software (FERREIRA, 2011).

\section{RESULTS}

Ammonia volatilization dynamic in maize crop field was similar in different environment (Chapadão do Sul and Selvíria) as shown in Figure 3 . The volatilization peak was observed after 3 days after coated or conventional urea supply. Ammonia volatilization decreased after 9 days of $\mathrm{N}$ fertilizer application on the maize crop (Figure 3). Similar results were found for all experiments and both environments tested.

There was significantly less $\mathrm{N}$ loss by volatilization in Chapadão do Sul in control plots (without $\mathrm{N}$ supply) at 3,6 and 9 days after $\mathrm{N}$ fertilization. Interestingly, significant difference $(\mathrm{p} \leq$ 0.05 ) was not found for $\mathrm{N}$ loss by volatilization between polymer-coated and conventional urea at 3, 6, 9, 12 and 15 days after $\mathrm{N}$ application. However, the total estimated $\mathrm{N}$ loss by volatilization accumulated for urea was approximately $34 \mathrm{~kg} \mathrm{~N}$ $\mathrm{ha}^{-1}$ (25\% of $\mathrm{N}$ applied to the soil), and for coated urea, the $\mathrm{N}$ loss by volatilization was approximately 
$26 \mathrm{~kg} \mathrm{~N} \mathrm{ha}^{-1}$ (19\% of $\mathrm{N}$ applied to the soil). These results suggest that polymer-coated urea has a positive effect on reducing $\mathrm{N}$ loss by volatilization under field conditions.



Figure 3. Ammonia volatilization dynamic after $\mathrm{N}$ fertilizer supply to the maize crop. A) first maize crop grown in Chapadão do Sul; B) first maize grown in Selvíria; C) second maize crop grown in Chapadão do Sul; D) second maize crop grown in Selvíria, State of Mato Grosso do Sul, Brazil.

Nitrogen loss by volatilization at the period of 3 days after fertilizer application was greater $(p \leq$ 0.05 ) for urea than for polymer-coated urea for first maize crop in Selviria (Table 3). For conventional urea source, $\mathrm{N}$ loss during the first 3 days was $54 \mathrm{~kg}$ $\mathrm{N} \mathrm{ha}^{-1}$, while for polymer-coated urea was observed approximately $39 \mathrm{~kg} \mathrm{~N} \mathrm{ha}^{-1}$. No difference of $\mathrm{N}$ loss by volatilization was observed after 3 days due to incorporation of $\mathrm{N}$ into the soil by the rain. The total accumulated $\mathrm{N}$ loss by volatilization for Selvíria (Table 3) showed the same tendency for the first 3 days after fertilizer application. Conventional urea showed values of $60 \mathrm{~kg} \mathrm{ha}^{-1}$ (44\% of $\mathrm{N}$ applied to the soil) while polymer-coated urea showed values around $42 \mathrm{~kg} \mathrm{ha}^{-1}$ (31\% of $\mathrm{N}$ applied to the soil).

For second maize crop grown in Chapadão do Sul (Table 3), no effect of polymer-coated and conventional urea on $\mathrm{N}$ loss by volatilization was observed. A similar result was also observed for total accumulated $\mathrm{N}$ losses by volatilization during the monitored period. The average values for $\mathrm{N}$ losses by volatilization were 52 and $57 \mathrm{~kg} \mathrm{~N}^{-1}$ for polymer-coated and conventional urea, respectively.
Nitrogen loss by volatilization at 3 and 9 days after fertilizer application was similar for polymer-coated and conventional urea for second maize crop in Selvíria (Table 3). Similar results was observed for total $\mathrm{N}$ loss accumulated throughout the period, which was approximately $27.5 \mathrm{~kg} \mathrm{~N} \mathrm{ha}^{-1}$ representing $20 \%$ of total $\mathrm{N}$ applied into soils. 
Table 3. Nitrogen loss by ammonia volatilization after fertilizer application to first and second maize crops grown in Chapadão do Sul and Selvíria, State of Mato Grosso do Sul, Brazil.

\begin{tabular}{|c|c|c|c|c|c|c|}
\hline \multirow{3}{*}{ N Source } & \multicolumn{6}{|c|}{$\mathrm{N}$ loss by ammonia volatilization $\left(\mathrm{kg} \mathrm{ha}^{-1}\right)$} \\
\hline & 3 & 6 & 9 & 12 & 15 & \multirow{2}{*}{ TOTAL } \\
\hline & \multicolumn{5}{|c|}{ Days after application } & \\
\hline & \multicolumn{5}{|c|}{ First maize crop in Chapadão do Sul } & \\
\hline Control (without N) & $1.07 \mathrm{~b}$ & $0.74 \mathrm{~b}$ & $0.42 \mathrm{~b}$ & 1.18 & 0.31 & $3.72 \mathrm{c}$ \\
\hline Urea & $24.50 \mathrm{a}$ & $4.38 \mathrm{a}$ & $3.45 \mathrm{a}$ & 1.29 & 0.76 & $33.85 \mathrm{a}$ \\
\hline \multirow[t]{2}{*}{ Coated urea } & $19.47 \mathrm{a}$ & $3.84 \mathrm{a}$ & $0.73 \mathrm{ab}$ & 0.85 & 0.75 & $26.18 \mathrm{~b}$ \\
\hline & \multicolumn{5}{|c|}{ First maize crop in Selvíria } & \\
\hline Control (without N) & $0.89 \mathrm{c}$ & 1.18 & 0.93 & 0.28 & 0.11 & $3.38 \mathrm{c}$ \\
\hline Urea & $54.43 \mathrm{a}$ & 2.91 & 0.72 & 1.21 & 0.54 & $59.80 \mathrm{a}$ \\
\hline \multirow[t]{2}{*}{ Coated urea } & $38.72 \mathrm{~b}$ & 2.00 & 1.21 & 0.18 & 0.32 & $42.43 \mathrm{~b}$ \\
\hline & \multicolumn{5}{|c|}{ Second maize crop in Chapadão do Sul } & \\
\hline Control (without N) & $2.20 \mathrm{~b}$ & $0.06 \mathrm{~b}$ & $0.01 \mathrm{~b}$ & 1.47 & 0.05 & $3.79 \mathrm{~b}$ \\
\hline Urea & $36.30 \mathrm{a}$ & $6.55 \mathrm{a}$ & $7.43 \mathrm{a}$ & 0.96 & 0.79 & $52.03 \mathrm{a}$ \\
\hline \multirow[t]{2}{*}{ Coated urea } & $41.17 \mathrm{a}$ & $6.72 \mathrm{a}$ & $7.17 \mathrm{a}$ & 1.96 & 0.59 & $57.61 \mathrm{a}$ \\
\hline & \multicolumn{5}{|c|}{ Second maize crop in Selvíria } & \\
\hline Control (without N) & $0.06 \mathrm{~b}$ & $0.10 \mathrm{~b}$ & $0.00 \mathrm{~b}$ & 0.13 & 0.01 & $0.30 \mathrm{~b}$ \\
\hline Urea & $26.42 \mathrm{a}$ & $0.58 \mathrm{~b}$ & $0.37 \mathrm{a}$ & 0.04 & 0.00 & $27.41 \mathrm{a}$ \\
\hline Coated urea & $25.21 \mathrm{a}$ & $1.31 \mathrm{a}$ & $0.34 \mathrm{a}$ & 0.18 & 0.43 & $27.47 \mathrm{a}$ \\
\hline $\begin{array}{l}\mathrm{CV}(\%) \\
\text { First maize crop in Chapadão do Sul }{ }^{1}\end{array}$ & 13.39 & 13.92 & 34.82 & 56.6 & 19.8 & 10.12 \\
\hline $\begin{array}{l}\mathrm{CV}(\%) \\
\text { First maize crop in Selvíria }{ }^{1}\end{array}$ & 9.94 & 24.17 & 16.44 & 27.60 & 27.40 & 8.11 \\
\hline $\begin{array}{l}\text { CV }(\%) \\
\text { Second maize crop in Chapadão do Sul }{ }^{1}\end{array}$ & 23.02 & 42.89 & 60.99 & 37.5 & 30.50 & 23.47 \\
\hline $\begin{array}{l}\text { CV }(\%) \\
\text { Second maize crop in Selvíria }{ }^{1}\end{array}$ & 20.14 & 13.71 & 9.34 & 33.30 & 29.10 & 15.63 \\
\hline
\end{tabular}

Averages followed by the same letter in the column are within $5 \%$ of each other by the Tukey probability test. ${ }^{1}$ Data transformed with $\sqrt{\mathrm{x}}+0.5$.

\section{DISCUSSION}

Experiment results from Nash et al. (2015) indicate that not more than $2 \%$ of $\mathrm{N}$ will be lost by volatilization if the fertilizer is applied immediately before rain with a volume high enough for $\mathrm{N}$ incorporation into soil. Interestingly, for both environments in this study, there was good rain precipitation after fertilizer application. The rain precipitation was around $21 \mathrm{~mm}$ for first maize crop and $22 \mathrm{~mm}$ for second maize crop on the same day that fertilizer was applied in Chapadão do Sul. Rain precipitation values for Selviria was approximately $23 \mathrm{~mm}$ for first maize crop and $18 \mathrm{~mm}$ for second maize crop on the same day after fertilizer application (Table 2).
Similar results for volatilization peak were also verified by Cantarella et al. (2008) in the state of São Paulo in Brazil. The authors observed that ammonia volatilization was higher during the second day after fertilizer application. Therefore, some studies show the highest ammonia volatilization starts after 20 hours urea application. Jantalia et al. (2012) observed ammonia volatilization peak at 7 days after urea fertilizer application. The authors found ammonia volatilization peak at 42 days after application for polymer-coated urea. It is important to note that the polymer used in this case had controlled release, unlike the product used in this study (which was soluble anionic urea). In addition, similar results were shown by Pereira et al. (2009), in which the $\mathrm{N}$ losses by ammonia volatilization were higher for 
urea than for polymer-coated urea and urea coated with a urease inhibitor.

Lara Cabezas et al. (2008) also measured N loss by ammonia volatilization from Brazilian soils. The authors found much higher levels of ammonia volatilization than those found in this study. Approximately $77 \%$ of total $\mathrm{N}$ applied as urea fertilizer, the authors observed a decrease of $38 \%$ and $8 \%$ from urea mixed with ammonium sulfate and pure ammonium sulfate, respectively.

Several studies shown decreases in $\mathrm{N}$ loss by volatilization with coated urea as reported by Francisco et al. (2011), Jantalia et al. (2012), Xu et al. (2013), Nash et al. (2015), Pan et al. (2016) and $\mathrm{Ke}$ et al. (2017). These results suggest the promising potential effect of fertilize technology on more sustainable agriculture.

It is interesting to note that soil humidity in the layers of the soil that are closer to the surface can directly influence total volatized N (MARTINS et al., 2015). In this study, there was a significant precipitation day before fertilizer was applied (Table 2 ), in all the experiments. This indicates the possibility of significant losses as seen in this study.

Atmosphere temperature is one factor affecting the ammonia volatilization from urea fertilizers (LIU et al., 2011). There is a strong positive relationship between atmospheric temperature and ammonia volatilization from urea. In this study, the less ammonia volatilization in maize second crop in comparison to the first crop is because the atmospheric temperature was lower during the urea fertilizer application (Figure 1).

No difference was observed regarding ammonia volatilization between urea a urea coated in during the maize second crop. The humidity, temperature and precipitation were sufficient to generate significant loss. However, the $\mathrm{pH}$ of the soil (Table 1) for the second harvest was lower than in the areas in which first harvest maize was grown, which could minimize this loss (LIU et al., 2011; XU et al., 2013).

\section{CONCLUSIONS}

There was a volatilization peak within the first three days after nitrogen-based fertilizer was applied, reaching levels of up to $44 \%$ of total N.

Polymer-coated urea had promising results, reducing the ammonia volatilization in maize first crop, but the same results was not found for maize second crop. Further studies are needed in order to better understand the ammonia volatilization using polymer-coated urea under different environment conditions.

\section{ACKNOWLEDGEMENTS}

The authors would like to thank: FAPESP (State of São Paulo Foundation for the Support of Reasearch - Brazil) for the doctoral grant for the primary author (Process 11/00315-6) and for paying part of the costs of the project; the PET group in the Agronomy and Forest Engineering Department of the Chapadão do Sul campus of UFMS for aid in evaluating the study; Fundação Chapadão (Foundation for the Support of Agriculture and Livestock of Chapadão) for allowing the use of the experimental area and the structure where the study was carried out.

RESUMO: A necessidade de mensurar adequadamente a emissão de gases e também o fornecimento de nutrientes às culturas por tecnologias como o revestimento da ureia com polímeros são necessários para monitar a possível poluição de fertilizantes nitrogenados no ambiente. Assim, o objetivo desse trabalho foi determinar as perdas de nitrogênio $(\mathrm{N})$ por volatilização pela ureia convencional e ureia revestida com polímero, em duas épocas de cultivo do milho (Zea mays L.), em duas regiões do cerrado brasileiro. Os trabalhos foram desenvolvidos em Chapadão do Sul e Selvíria, Mato Grosso do Sul - Brasil, na cultura do milho "primeira safra" e "segunda safra", respectivamente. Os tratamentos foram constituídos pela ureia e ureia revestida por polímero aplicada em cobertura além de um tratamento controle (sem N) em função de épocas de monitoramento das perdas de $\mathrm{N}$ por volatilização $(3,6,9,12$ e 15 dias após a adubação) com 5 repetições. Foi mensurado as perdas de $\mathrm{N}$ por volatilização nas respectivas épocas e o total acumulado no período. O pico de volatilização ocorreu durante os três primeiros dias, atingindo patamares de até $44 \%$ do total de $\mathrm{N}$ fornecido. $\mathrm{O}$ revestimento da ureia com polímeros apresentou resultados promissores, diminuindo as perdas de $\mathrm{N}-\mathrm{NH}_{3}$ por volatilização no milho "primeira safra". Todavia, os resultados obtidos no milho "segunda safra" não permitem generalizar tais benefícios.

PALAVRAS-CHAVE: Perdas de N. Uso eficiente de fertilizantes. Cerrado. Polímero. Sistema plantio direto. 


\section{REFERENCES}

ADEWOPO, J. B.; VANZOMEREN, C. V.; BHOMIA, R. K.; ALMARAZ, M.; BACON, A. R.; EGGLESTON, E.; MOOBERG, C.; SNYDER, E.H.; TIEDEMAN, M. Top-Ranked Priority Research Questions For Soil Science In The $21^{\text {st }}$ Century. Soil Science Society of American Journal, Madison, v. 78, $\mathrm{n}$. 2, p. 337-347, 2014. http://dx.doi.org/10.2136/sssaj2013.07.0291.

CANTARELlA, H.; TRIVELIN, P. C. O.; CONTIN, T. L. M.; DIAS, F. L. F.; ROSSETTO, R.; MARCELINO, R.; COIMBRA, R. B.; QUAGGIO, J. A.. Ammonia volatilization from urease inhibitor-treated urea applied to sugarcane trash blankets. Scientia Agrícola, Piracicaba, v. 65, n. 4, p. 397-401, 2008. http://dx.doi.org/10.1590/S0103-90162008000400011.

CHIEN, S. H.; PROCHNOW, L. I.; CANTARELLA, H. Recent developments of fertilizer production and use to improve nutrient efficiency and minimize environmental impacts. Advances in Agronomy, New York, v. 102, n. 1, p. 267-322, 2009. http://dx.doi.org/10.1016/S0065-2113(09)01008-6.

FERREIRA, D. F. Sisvar: a computer statistical analysis system. Ciência e Agrotecnologia, Lavras, v. 35, n. 6, p. 1039 - 1042, 2011. http://dx.doi.org/10.1590/S1413-70542011000600001.

FRANCISCO, S. S.; URRUTIA, O.; MARTIN, V.; PERISTEROPOULOS, A.; GARCIA-MINA, J. M. Efficiency of urease and nitrification inhibitors in reducing ammonia volatilization from diverse nitrogen fertilizers applied to different soil types and wheat straw mulching. Journal of the Science of Food and Agriculture, v. 91, n. 9, p. 1569-1575, 2011. http://dx.doi.org/10.1002/jsfa.4349.

JANTALIA, C. P.; HALVORSON, A. D.; FOLLETT, R. F.; ALVES, B. J. R.; POLIDORO, J. C.; URQUIAGA, S. Nitrogen source effects on ammonia volatilization as measured with semi-static chambers. Agronomy Journal, New York, v. 104, n. 6, p. 1595-1603, 2012. http://dx.doi.org/10.2134/agronj2012.0210.

KANEKO, F. H.; SABUNDJIAN, M. T.; FERREIRA, J. P.; GITTI, D. C.; NASCIMENTO, V.; LEAL, A. J. F.; BUZETTI, S.; REIS; A. R.; ARF, O. Synergistic effects of seed inoculation with Azospirillum brasilense and nitrogen sources on double cropped maize production in tropical savanna of Brazil. Australian Journal of Crop Science, v. 10, n. 7, p. 1061 - 1068, 2016. http://dx.doi.org/10.21475/ajcs.2016.10.07.p7895.

KE, J.; XING, X.; LI, G.; DING, Y.; DOU, Y.; WANG, S.; LIU, Z.; TANG, S.; DING, C.; CHEN, L. Effects of different controlled-release nitrogen fertilisers on ammonia volatilisation, nitrogen use efficiency and yield of blanket-seedling machine-transplanted rice. Field Crops Research, Amsterdam, v. 205, n. 1, p.147-156, 2017. http://dx.doi.org/10.1016/j.fcr.2016.12.027.

LARA CABEZAS, W. A. R.; SOUZA, M. A. Ammonia volatilization, leaching of nitrogen and corn yield in response to the application of mix of urea and ammonium sulphate or gypsum. Revista Brasileira de Ciência do solo, Viçosa, v. 32, n. 6, p. 2331-2342, 2008. http://dx.doi.org/10.1590/S0100-06832008000600012.

LARA CABEZAS, W. A. R.; TRIVELIN, P. C. O.; BENDASSOLLI, J. A.; SANTANA, D. G.; GASCHO, G. J. Calibration of a semi-open static collector for determination of ammonia volatilization from nitrogen fertilizers. Communications in Soil Science \& Plant Analysis, v. 30, n.3, p. 389-406, 1999.

http://dx.doi.org/10.1080/00103629909370211.

LIU, G.; LI, Y.; MIGLIACCIO, K. W.; OUYANG, Y.; ALVA, A. K. Identification of Factors Most Important for Ammonia Emission from Fertilized Soils for Potato Production Using Principal Component Analysis.

Journal of Sustainable Watershed Science \& Management, New York, v. 1, n. 1, p. 21-30, 2011.

http://dx.doi.org/10.5147/jswsm.2011.0037. 
MARTINS, M. R.; JANTALIA, C. P.; POLIDORO, J. C.; BATISTA, J. N.; ALVES, B. J. R.; BODDEY, R. M.; URQUIAGA, S.. Nitrous oxide and ammonia emissions from $\mathrm{N}$ fertilization of maize crop under no-till in a Cerrado soil. Soil \& Tillage Research, v. 151, n. 1, p. 75-81, 2015.

http://dx.doi.org/10.1016/j.still.2015.03.004.

NASCIMENTO, C. A. C.; VITTI, G. C.; FARIA, L. A, LUZ, P. H. C.; MENDES, F. L. Ammonia volatilization from coated urea forms. Revista Brasileira de Ciência do Solo, Viçosa, v. 37, n. 4, p. 10571063, 2013. http://dx.doi.org/10.1590/S0100-06832013000400022.

NASH, P.; MOTAVALLI, P.; NELSON, K.; KREMER, R. Ammonia and nitrous oxide gas loss with subsurface drainage and polymer-coated urea fertilizer in a poorly drained soil. Journal of Soil and Water Conservation, Ankeny, v. 70, n. 4, p. 267-275, 2015. http://dx.doi.org/10.2489/jswc.70.4.267.

NOMMIK, H. 1973. The effect of pellet size on the ammonia loss from urea applied to forest soil. Plant and Soil, Crawley, 39, 309-318. http://www.jstor.org/stable/42932391.

PAN, B.; LAM, S. K.; MOSIER, A.; LUO, Y.; CHEN, D. Ammonia volatilization from synthetic fertilizers and its mitigation strategies: A global synthesis. Agriculture, Ecosystems and Environment, v. 232, n. 1, p. 283 - 289, 2016. https://doi.org/10.1016/j.agee.2016.08.019.

PEREIRA, H. S.; LEÃO, A. F.; VERGINASSI, A.; CARNEIRO, M. A. C. Ammonia volatilization of urea in the out-of-season corn. Revista Brasileira de Ciência do Solo, Viçosa, v. 33, n. 6, p. 1685-1694, 2009. http://dx.doi.org/10.1590/S0100-06832009000600017.

RAVINSHANKARA, A. R.; DANIEL, J. S.; PORTMANN, R. W. Nitrous oxide $\left(\mathrm{N}_{2} \mathrm{O}\right)$ : the dominant ozonedepleting substance emitted in the 21st century. Science, Washington, v. 326, n. 1, p. 123-125, 2009.

http://dx.doi,org/10.1126/science.1176985 .

RAYMOND, J. E.; FOX, T. R.; STRAHM, B. D.; ZERPA, J. Ammonia volatilization following nitrogen fertilization with enhanced efficiency fertilizers and urea in loblolly pine (Pinustaeda L.) plantations of the southern United States. Forest Ecology and Management, v. 376, n.1, p.247-255, 2016.

http://dx.doi.org/10.1016/j.foreco.2016.06.015.

SANTOS, H. G.; JACOMINE, P. K. T.; ANJOS, L. H. C.; OLIVEIRA, V. A.; LUMBRERAS, J. F.; COELHO, M. R.; ALMEIDA, J. A.; CUNHA, T. J. F.; OLIVEIRA, J. B. de. Sistema brasileiro de classificação de solos. 3.ed. Brasília: Embrapa, 2013. 353p.

SHI, W.; XU, W.F.; LI, S. M.; ZHAO, X.Q.; DONG, G. Q. Responses of two rice cultivars differing in seedling-stage nitrogen use efficiency to growth under low nitrogen conditions. Plant and Soil, v. 326, n. 1, p. 291-302, 2010. http://dx.doi.org/10.1104/pp.91.3.1152.

SOARES, J. R.; CANTARELLA, H.; MENEGALE, C. Ammonia volatilization losses from surface-applied urea with urease and nitrification inhibitors. Soil Biology \& Biochemistry, v. 52, n. 1, p. 82-89, 2012. http://dx.doi.org/10.1016/j.soilbio.2012.04.019.

SUN, H.; ZHANG, H.; POWLSON, D.; MIN, J. SHI, W. Rice production, nitrous oxide emission, and ammonia volatilization as impacted by nitrification inhibitor 2-chloro-6-(Trichloromethyl)-pyridine. Field Crops Research, Amsterdam, v. 173, n.1, p. 01-07, 2015. http://dx.doi.org/10.1016/j.fcr.2014.12.012.

XU, M.; LI, D.; LI, J.; QIN, D.; HOSEN, Y.; SHEN, H.; CONG, R.; HE, X. Polyolefin-coated urea decreases ammonia volatilization in a double rice system of Southern China. Agronomy Journal, New York, v. 105, n. 1, p. 277-284, 2012. http://dx.doi.org/10.2134/agronj2012.0222. 
ZAVASCHI, E.; FARIA, L. A.; VITTI, G. C.; NASCIMENTO, C. A. C.; MOURA, T. A.; VALE, D. W.; MENDES, L.; AND KAMOGAWA, M. Y. Ammonia volatilization and yield components after application of polymer-coated urea to maize. Revista Brasileira de Ciência do solo, Viçosa, v. 38, n. 4, p. 1200-1206, 2014. http://dx.doi.org/10.1590/S0100-06832014000400016. 